\title{
Differentiating mature and old-growth forests in the Upper Foothills and Subalpine Subregions of west-central Alberta ${ }^{1}$
}

\author{
by Luigi E. Morgantini ${ }^{2}$ and John L. Kansas ${ }^{3}$
}

\begin{abstract}
Weyerhaeuser Company Ltd. is developing harvest strategies that will maintain appropriate levels of late to very late seral stages ("old growth") in its Drayton Valley Forest Management Area. This management area encompasses 490570 ha in the Foothills and Rocky Mountain Natural Regions of west-central Alberta. In planning for future forest landscapes, Weyerhaeuser intends to maintain a range of age structures consistent with the ecological processes characteristic of each natural region and subregion. The absence of a discrete point separating mature forest from old growth means that the age at which a stand is currently identified as "old growth" and subject to special management practices is arbitrary. In a research study initiated in the summer of 2000, we seek to understand the differences in structure and composition between forests of various ages and topographic site conditions (elevation, aspect, and slope angle). Using 95 sampling plots in a $123-\mathrm{km}^{2}$ study area in the Upper Foothills and Subalpine Natural Subregions, we quantified vegetation structure and composition for stands ranging in age from 70 to 300 years. Variables measured and analysed included live-tree height and diameter, snag density, diameter and decay class, downed woody material volume, diameter and decay class, vascular plant species richness, sapling and regeneration density, and duff depth. An old-growth index was developed for each sampled stand that took into account multiple attributes. Preliminary results indicate that specific attributes (snag basal area and density, decay stage and density of downed woody material, variation in live-tree age, and variation in live-tree height and age) separate a younger forest from a more mature one and hence may describe "old-growth" conditions. The age of onset of these old-growth attributes is variable but appears to occur between 160 and 180 years. Key factors other than stand age that contribute to or modify the development of old-growth attributes (as measured by the old-growth index) are elevation and moisture regime (as modified by site position). Further investigation is required to more accurately assess the effect of site factors on old-growth attributes. These results are now used by Weyerhaeuser to address retention of late seral stages in long-term forest planning.
\end{abstract}

Key words: old growth, mature forests, old growth protection, forest management, Alberta, Weyerhaeuser, Rocky Mountains foothills

La société Weyerhaeuser Ltd. met au point des stratégies de récolte qui conserveront les quantités convenables de stades sériaux d'âgés à très âgés ( «vieilles forêts ») dans sa zone d'aménagement forestier de Drayton Valley. Cette ZAF couvre 490570 ha des régions naturelles des Rocheuses et de leurs contreforts, dans le Centre-Ouest de l'Alberta. Dans la planification des futurs paysages forestiers, Weyerhaeuser a l'intention de maintenir toute une gamme de structures d'âges compatibles avec les processus écologiques caractéristiques de chaque région et sous-région naturelles. L'absence d'un point précis séparant la forêt parvenue à maturité de la vieille forêt signifie que l'âge à partir duquel on qualifie le peuplement de vieux et on le soumet à des pratiques particulières d'aménagement est arbitraire. Dans une recherche entreprise au cours de l'été 2000, nous avons voulu élucider les différences de structure et de composition entre les forêts de divers âges et conditions topographiques (altitude, orientation et valeur angulaire de la pente). À l'aide de 95 placettes d'échantillonnage dans une zone couvrant $123 \mathrm{~km}^{2}$, dans les sous-régions naturelles subalpines et des hauts contreforts des Rocheuses, nous avons quantifié la structure et la composition de peuplements dont l'âge variait de 70 à 300 ans. Les variables mesurées et analysées comprenaient la hauteur et le diamètre des arbres vivants, la densité ainsi que les classes de diamètre et de décomposition des chicots, le volume ainsi que les classes de diamètre et de décomposition des débris ligneux jonchant le sol, la richesse en espèces vasculaires, la densité des gaulis et de la régénération ainsi que l'épaisseur de la litière. Pour chaque peuplement échantillonné, on a calculé un indice de vieillesse fondé sur diverses caractéristiques. Selon les résultats préliminaires, des caractéristiques précises (surface terrière et densité des chicots, stade de la décomposition et densité des débris ligneux jonchant le sol, variation de l'âge des arbres vivants et variation de la hauteur et de l'âge des arbres vivants) permettent de distinguer une forêt jeune d'une forêt arrivée à maturité et, de là, permettent de décrire les conditions dans lesquelles on a affaire à une vieille forêt. L'âge auquel on commence à observer ces caractéristiques de vieille forêt varie, mais semble se situer entre 160 et 180 ans. D'autres facteurs clés que l'âge du peuplement qui contribuent à l'apparition des caractéristiques de vieille forêt (mesurées par un indice de même nom) ou influent sur leur évolution sont l'altitude et le régime hydrique (modifiés par l'emplacement de la station). D'autres études sont nécessaires pour évaluer avec plus de précision l'effet des facteurs stationnels sur les caractéristiques des vieilles forêts. Ces résultats sont désormais utilisés par Weyerhaeuser pour résoudre le problème de la conservation des stades sériaux tardifs en planification forestière à long terme.

Mots clés : vieilles forêts, amenagement forestièr, protection des vieilles forêts, Alberta, Weyerhaeuser, contreforts des Rocheuses

\footnotetext{
${ }^{1}$ Paper presented at the "Old-growth Forests in Canada: A Science Perspective" Conference, October 14-19, 2001, Sault Ste. Marie, ON.

${ }^{2}$ Weyerhaeuser Company Ltd., $11553-154^{\text {th }}$ Street, Edmonton, Alberta T5M 3N8. E-mail: luigi.morgantini@weyerhaeuser.com

${ }^{3}$ URSUS Ecosystem Management Ltd., 3426 Lane Crescent S.W., Calgary, Alberta T3E 5X2
}

\section{Introduction}

There is no wide agreement on what constitutes "old growth." Peterson et al. (1995) listed 26 different definitions from different authors and geographic areas. In general, all definitions refer to old growth as being a unique successional stage in the life of a plant community, where the structural and compositional features support specific old-growth ecological 
processes. The State of Canada's Environment (cited in Watson 1993) classified old-growth forests as those where trees are 140 years or older. This contrasts with the 275- to 300-year range for coniferous forests referred to by Achuff (1989) for Canada's five Rocky Mountain National Parks. In the United States, the Forest Service has characterized old growth as "later stage(s) in forest development which may be distinctive in composition but are always distinctive in structure from earlier (young and mature) successional stages" (Moir 1992). However, Hunter and White (1997), after an extensive review of numerous studies on forest ecology and development, concluded that there is no evidence of the existence of distinct thresholds between mature forest and old growth. Forest succession and development is a continuum of changes in structures and composition where no specific age can provide an "unambiguous threshold on which to base a definition" (Hunter and White 1997).

It is widely agreed that late seral stages (old growth) are an important underpinning of the biological diversity of forested landscapes and that a certain amount should be retained in managed landscapes. Retention of an appropriate quantity and distribution of old-growth forest is a stated policy objective of the Alberta Forest Conservation Strategy (AFCSSC 1997). Advanced stages of forest succession lead to canopy break-up, release of understorey plants, accumulation of snags and downed logs, and the emergence of secondary canopy species (Peterson et al. 1995, Schneider 2000). Typically, structural diversity is greatest in older forest stands (Clark et al. 1998, Burton et al. 1999, Lee et al. 2000). This diversity tends to result in diverse plant and wildlife communities that differ significantly from those found in younger stands (Farr 1993, Roy et al. 1995, Kirk et al. 1996, Gandhi et al. 2001).

The lack of an age at which mature forest can be distinguished from old growth poses a challenge to forest managers. Forest management practices, and specifically the need to set constraints on long-term harvesting of merchantable forests, require that specific ages are identified to ensure that a certain amount of late seral stages (old growth) older than economically based rotation age is sustained.

\section{Weyerhaeuser's Approach in Alberta}

In the absence of an agreed definition of old growth, Weyerhaeuser Company committed to maintain a certain amount of forest older than rotation age (approx. 90-110 years old) in its Forest Management Areas (FMA) in Alberta. The distribution of age classes across a landscape, and thus the amount of late seral stages, varies depending on the length of time since the last fire disturbance and the fire cycle of the region. In Alberta, fire regimes differ among natural subregions depending on climate, tree species dominance, and even historical lightning strikes. Natural subregions with cooler, wetter climates and less lightning activity have longer fire cycles.

Weyerhaeuser intends to maintain a range of age structures consistent with the ecological processes characteristic of each subregion. These subregion-specific age structures will determine the percentage of forest in late seral stages that will be maintained over the planning horizon. In addition to these minimum amounts, Weyerhaeuser will reserve from harvest any rare old stands as they are identified within the FMA areas. Furthermore, current Weyerhaeuser practices to retain stand-level structure in cutblocks (i.e., retention of large live and dead trees) will provide structural diversity in regenerat-

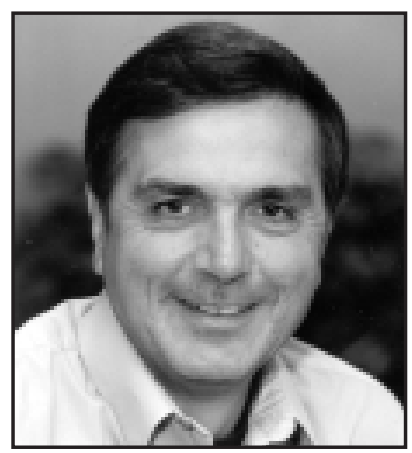

Luigi E. Morgantini

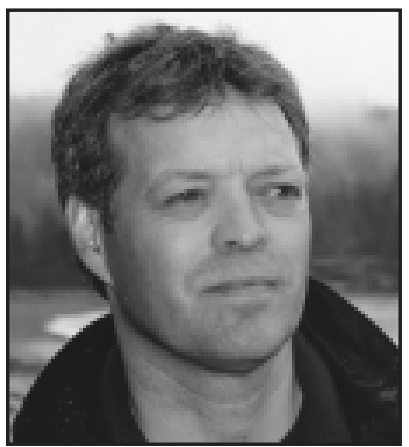

John L. Kansas ing forests and create some old forest structures throughout the rotation. Similarly, residual patches of $>0.5$ ha will retain some old-forest characteristics in cutblocks immediately after harvest, and smaller patches and single residual trees may create old-forest structural characteristics late in rotation.

The absence of a discrete point separating mature forest from old growth means that the age at which a stand is currently identified as old growth, and thus subject to special management practices or protected, is arbitrary. Nonetheless, identifying age thresholds that can be used for long-term planning in forest management is necessary. Distinguishing and classifying oldgrowth forest from younger mature stages based on vegetation structure and composition is fundamental to meeting Weyerhaeuser's age structure maintenance objectives over the planning horizon.

In northern forests, fire plays an important function in determining the variety of vegetation patterns observed on a landscape. The type, duration, severity, and size of fire determine post-fire vegetation composition and succession (Johnson 1992). However, fires and fire regimes differ greatly across and within geographical regions, and are influenced by a number of factors including climate, weather, vegetation composition, stand age, topography, and others (Rogeau 1996). Knowledge of the nature and extent of changes in structure and composition of forest stands during mid to late succession in the Foothills and Subalpine Regions of Alberta is currently limited. Most investigations on this topic have been conducted in aspen mixedwood forests located in the Dry and Central Boreal Mixedwood Subregions of east-central Alberta (Stelfox 1995, Lee et al. 2000). Extrapolation of these findings to the Rocky Mountains and Foothills may not be relevant and could even be misleading because of fundamental differences in climate and disturbance regimes. The main objectives of the research program initiated by Weyerhaeuser were: 1) to evaluate how forest structure and composition change during mature to late seral stand development, and 2) to determine which environmental factors are primarily responsible for inducing those changes. This benchmark information may then be used to classify, map, and maintain old-growth forest conditions elsewhere in the region. Here we highlight some initial results of the research program.

\section{Study Area}

The $123-\mathrm{km}^{2}$ study area (Fig. 1) is located in the Central Foothills District of the Rocky Mountain Foothills Physiographic Region of Alberta (Pettapiece 1986) in west-central Alberta $\left(52^{\circ} 30^{\prime} \mathrm{N}\right.$ 


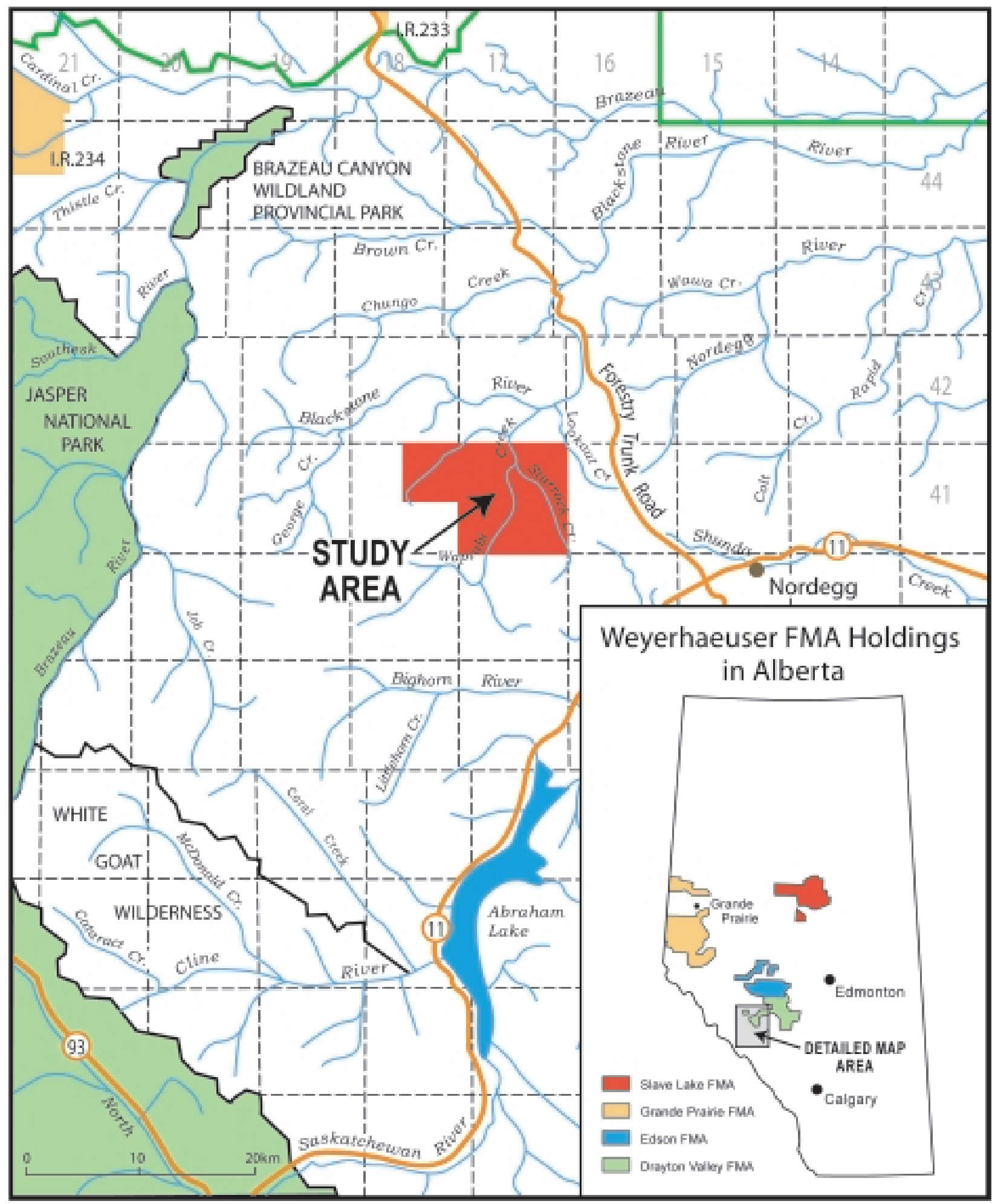

Fig. 1. Study area location in the context of Weyerhaeuser's Forest Management Area holdings in Alberta.

to $52^{\circ} 35^{\prime} \mathrm{N} ; 116^{\circ} 18^{\prime} \mathrm{W}$ to $\left.116^{\circ} 32^{\prime} \mathrm{W}\right)$. The sites sampled are in the Upper Foothills and Subalpine Natural Subregions (Alberta Environmental Protection 1994), and lie within Weyerhaeuser's Drayton Valley Forest Management Area. Sampled stands are transitional between the Boreal Forest and Rocky Mountain Natural Regions and occur at elevations between 1460 to $1970 \mathrm{~m}$ above sea level. The boreal climate of the Upper Foothills subregion (1460 to $1730 \mathrm{~m}$ ) is substantially modified by the Rocky Mountains, as reflected by cool summer temperatures and ameliorated winter temperatures. The mean summer (May-August) and winter (November-February) temperatures are 11.5 and $-6.0^{\circ} \mathrm{C}$, respectively. Subalpine (1730-2000 m) 


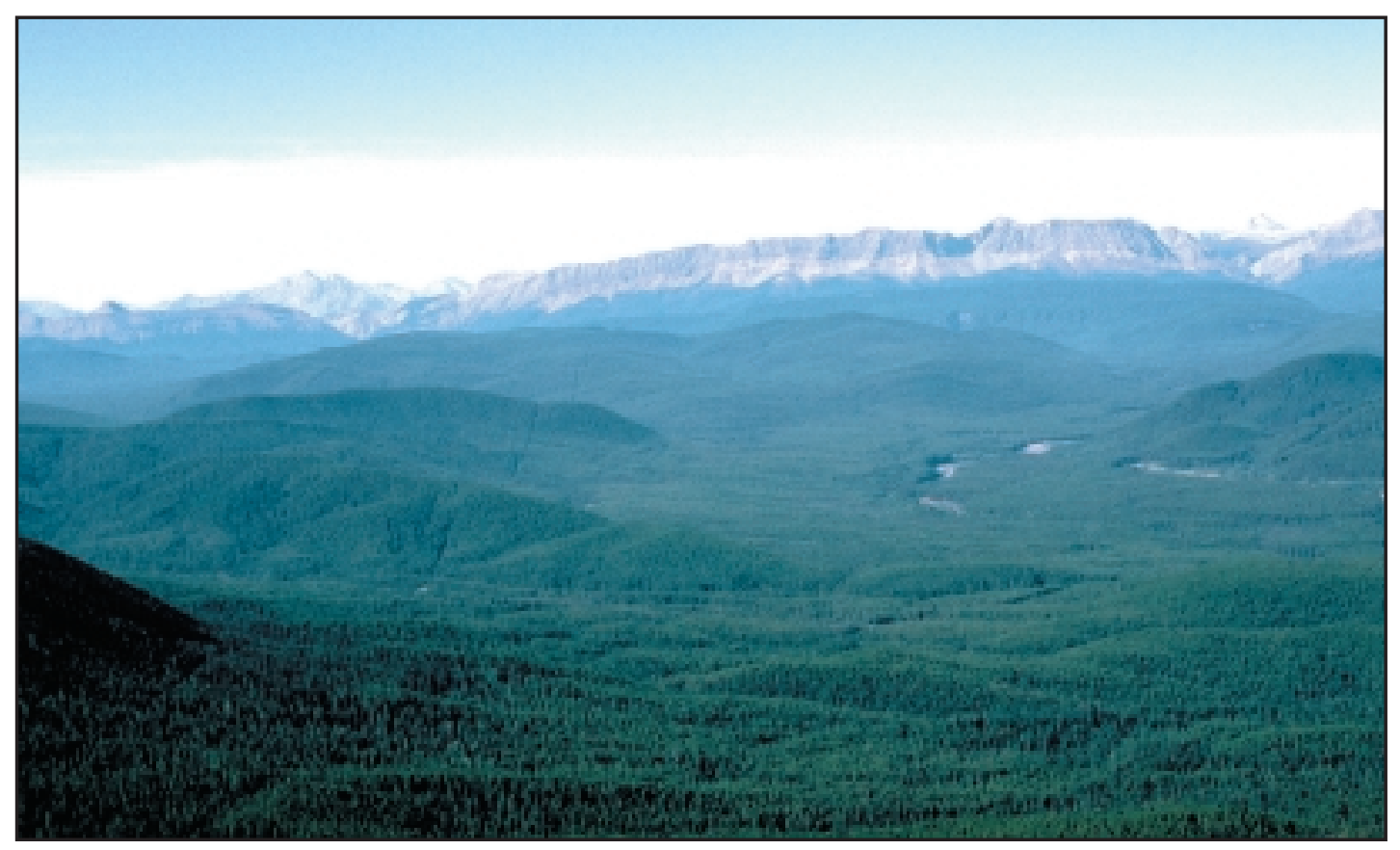

Fig. 2. Panoramic view of conifer-dominated forests of the Upper Foothills and Subalpine subregions in the study area.

mean temperatures are $9.4^{\circ} \mathrm{C}$ in summer and $-8.9^{\circ} \mathrm{C}$ in winter (Strong 1992). The precipitation regime in the Upper Foothills is continental with 55\% of total precipitation falling during the May to September period (Wehrhan 1982). The median annual precipitation in the Upper Foothills subregion is 538 $\mathrm{mm}$. Median annual precipitation in the Subalpine Subregion is $568 \mathrm{~mm}$, with $53.6 \%$ falling during the winter months, reflecting the increased influence of warm, moist Pacific air masses. Growing conditions for trees are much more favourable in the Upper Foothills (752 growing degree days) than in the Subalpine (558 growing degree days)

The higher elevation western portion of the study area is located primarily in the Subalpine subregion and is characterized by steeply sloping colluvium associated with the east flank of the Bighorn Range. An upper tributary of the Blackstone River drains the northern portion of this area. The eastern twothirds of the study area lie primarily within the Upper Foothills subregion. This area is dominated by rolling till plain and to a lesser extent colluvial ridges that are oriented in a northwestern to southeastern direction. Alluvial and glacio-fluvial deposits occur in association with the Wapiabi Creek and Sturrock Creek flood plains.

Coniferous forest covers most of the study area (Fig. 2). The primary tree species in the Upper Foothills subregion is lodgepole pine (Pinus contorta Dougl. ex Loud.), which is widespread on till plains and lower colluvial slopes. White spruce (Picea glauca (Moench) Voss) occurs locally along flood plain alluvium and on steep northerly exposures. A minor amount of black spruce (Picea mariana (Mill.) B.S.P.) occurs in the Upper Foothills on poorly drained sites. The primary tree species in the Subalpine subregion are spruce hybrids of Picea engelmanni Parry ex Engelm. and $P$. glauca. Subalpine fir (Abies lasiocarpa (Hook.) Nutt.) occurs in widespread association with spruce. Based on Alberta Vegetation Inventory (AVI) mapping, major fire events in the area occurred during the following decades: 1760, 1800, 1840, 1860, and 1890.

\section{Methods}

A total of 95 forest stands were sampled. Criteria for selection of stands included (1) minimum date of origin of 1920 or older; (2) canopy closure greater than or equal to 25\%; (3) sub-hygric moisture regime or drier; (4) predominantly coniferous; and (5) no or minimal human influence. Within each of the 95 stands, a single $20-\mathrm{m}^{2}$ plot was located within a relatively homogeneous area. The elevation, slope angle, and aspect of each site were measured and the moisture regime was described.

Five sampling points were placed within the $20-\mathrm{m}^{2}$ plot. Diameter at breast height (dbh) was recorded for the selected live trees and for snags. The point-centred quarter method (Mueller-Dombois and Ellenberg 1974) was used to select 20 live trees $(>10 \mathrm{~cm}$ $\mathrm{dbh}$ ) and 20 standing dead trees ( $>10 \mathrm{~cm}$ dbh and $>2 \mathrm{~m}$ in height) for more detailed sampling, and to estimate stem densities. Heights were determined for live trees and snags using a Vertex III transponder. The species of snag was determined when possible and the degree of decay was estimated using a six-class system from Lee et al. (1995). Stand age was determined by taking increment cores from all 20 live trees in each sampled stand and assigning the stand age to equal the oldest tree that was no more than 10 years older than another tree in the stand (Clark et al. 1998). The diameter of all downed woody material (DWM) greater than $10 \mathrm{~cm}$ was measured along five equally spaced and parallel 20 -m long transects, two of which formed the boundaries of the larger $20-\mathrm{m}^{2}$ sampling quadrat. The point (to the nearest $\mathrm{cm}$ ) at which the centre of each DWM intersected the transect lines was recorded. The decay class of each DWM was recorded using a seven-class system from Lee et al. (1995). Rectangular $2 \times 5$-m plots were established at each of the five sampling points. The number and height of each tree sapling $(>1.0$ and $<7.1 \mathrm{~cm} \mathrm{dbh})$ and tree regeneration ( $>0.3 \mathrm{~m}$ tall and $<1.1 \mathrm{~cm}$ dbh) was recorded within each of the sampling points. Also recorded for each sampling point 
Table 1. Attributes and measures used to assess change in forest with stand age

\begin{tabular}{|c|c|c|}
\hline Category & Attribute & Measure \\
\hline Downed woody material (DWM) & $\begin{array}{l}\text { DWM volume* } \\
\text { DWM density* } \\
\text { DWM diameter* } \\
\text { DWM decay } \\
\text { DWM diameter variation* } \\
\text { DWM decay class variation* }\end{array}$ & $\begin{array}{l}\mathrm{m} 3 / \text { ha of DWM }>10-\mathrm{cm} \text { diameter } \\
\text { \# Intercepts of DWM }>10 \mathrm{~cm} \text { per } 100 \mathrm{~m} \\
\text { Mean diameter of DWM at intercept } \\
\text { Mean decay class (Lee } \text { et al. } 1995) \\
\text { Mean (within-stand) coefficient of variation of DWM }(>10 \mathrm{~cm}) \text { diameter } \\
\text { Mean (within-stand) coefficient of variation of CWD }(>10 \mathrm{~cm}) \text { decay class }\end{array}$ \\
\hline Standing dead material (Snags) & $\begin{array}{l}\text { Snag basal area* } \\
\text { Snag density* } \\
\text { Snag height } \\
\text { Snag diameter* } \\
\text { Snag decay } \\
\text { Snag height variation* } \\
\text { Snag diameter variation* } \\
\text { Snag decay variation } \\
\text { Snag spacing variation* }\end{array}$ & $\begin{array}{l}\text { Basal area }\left(\mathrm{m}^{2} / \mathrm{ha}\right) \\
\text { \# Snags }(>10 \mathrm{~cm} \mathrm{dbh}) / \text { ha } \\
\text { Mean snag height } \\
\text { Snag diameter at breast height }(\mathrm{dbh}) \\
\text { Mean decay class (Lee } \text { et al. } 1995) \\
\text { Mean (within-stand) coefficient of variation of height of snags }(>10 \mathrm{~cm}) \\
\text { Mean (within-stand) coefficient of variation of snag }(>10 \mathrm{~cm} \text { dbh) } \\
\text { Mean (within-stand) coefficient of variation of snag decay class. } \\
\text { Mean (within-stand) coefficient of variation of distance to nearest snag form } \\
\text { point-centred quarter method. }\end{array}$ \\
\hline Live trees & $\begin{array}{l}\text { Live-tree basal area } \\
\text { Live-tree stem density } \\
\text { Live-tree height* } \\
\text { Live-tree diameter* } \\
\text { Live-tree height variation* } \\
\text { Live-tree diameter variation* } \\
\text { Live-tree age variation* } \\
\text { Live-tree spacing variation* }\end{array}$ & $\begin{array}{l}\text { Basal area }\left(\mathrm{m}^{2} / \mathrm{ha}\right) \\
\text { \# Trees }(>10 \mathrm{~cm} \mathrm{dbh}) / \mathrm{ha} \\
\text { Mean live-tree height } \\
\text { Live-tree diameter at breast height }(\mathrm{dbh}) \\
\text { Mean (within-stand) coefficient of variation of height of trees }(>10 \mathrm{~cm}) \\
\text { Mean (within-stand) coefficient of variation of tree }(>10 \mathrm{~cm}) \mathrm{dbh} \\
\text { Mean (within-stand) coefficient of variation of live-tree age. } \\
\text { Mean (within-stand) coefficient of variation of distance to nearest tree form } \\
\text { point-centred quarter method }\end{array}$ \\
\hline Tree regeneration & $\begin{array}{l}\text { Regenerating tree density* } \\
\text { Sapling tree density* }\end{array}$ & $\begin{array}{l}\text { \# Stems/ha of trees }(>0.3 \mathrm{~m} \text { tall and }>1.1 \mathrm{~cm} \mathrm{dbh}) \\
\text { \# Stems/ha of trees }(>1.0 \text { and }>7.1 \mathrm{~cm} \mathrm{dbh})\end{array}$ \\
\hline Ground layer & $\begin{array}{l}\text { Forb species richness } \\
\text { Duff depth* }\end{array}$ & $\begin{array}{l}\text { mean \# forb species per plot } \\
\text { Mean depth to organic layer }(\mathrm{cm})\end{array}$ \\
\hline
\end{tabular}

*Variables used for old-growth index.

was the percent cover of all low $(<2.5 \mathrm{~m}$ tall $)$ and tall (2.5-5.0 m) shrub species.

Forest variables were selected from each of five categories: downed woody material (deadfall), standing dead trees (snags), live (canopy) trees, low and tall understorey (tree regeneration), and ground layer. Twenty-seven variables were sampled that, based on a review of old growth literature, had potential to represent changing structure or composition with changing stand age (Table 1). Sampled stands were grouped into eight age classes (70-115; 116-130; 131-150; 151-170; 171-190; 191-210; 211-230; > 230 years). Single-classification analysis of variance (ANOVA) was used to test for differences in each variable among stand ages. Tukey's multiple comparisons test (Neter et al. 1990) was used to assign post hoc differences among stand ages. A 5\% significance level was used throughout.

The 95 sampling plots were ordinated for 20 of the 27 oldgrowth attributes as highlighted in Table 1 . This was done by rank, ordering the plots according to their values for each attribute and then grouping sampling plots within deciles (i.e., scores of 1 to 10). A preliminary old-growth index was then calculated for each plot by summing scores across all attributes. Plots with high cumulative scores were assumed to support stand size, structure, and variability indicative of old growth. Multiple regression was used to assess which of five environmental variables (age, elevation, aspect, slope angle, percent composition lodgepole pine in tree canopy) affected old-growth index scores significantly and appreciably and to estimate the relative magnitudes of the contributions of these variables.

\section{Results and Discussion}

This study examined changes in vegetation and age structure and composition as forest stands progress from a maturing seral stage through to older stands that approximate "climax" conditions. Stands sampled ranged in age from 70 to 300 years. Identifying the stage at which old growth enters this successional continuum is the challenge. Table 2 provides mean values for each sampled attribute and age class. Table 3 summarizes the results of univariate analyses of change in stand attributes with stand age. Mean values for ten of the 27 variables assessed were significantly different between at least one pair of stand ages $(P<0.05$; Table 2$)$. Variables with two or more significant paired comparisons were snag basal area $(n=6)$, downed woody material decay class $(n=4)$, downed woody material density $(n=3)$, downed woody material decay variability $(n=3)$, and live tree height variability $(n=3)$. Variables with a single significant paired comparison were snag density, snag decay class, snag height variability, livetree age variability, and forb species richness. Of the $24 \mathrm{sig}$ nificant paired comparisons, 15 involved differences between the 70- to 115-year age class and forests older than 171 years. Paired comparison probabilities for variables within the four youngest (70-170 years) and the four oldest (171-230+ years) age classes rarely differed significantly (Table 2). Of the ten significant variables, all but decay level increased with increasing stand age.

Changes in old-growth attributes with stand age are discussed below in the context of major successional stages for forest com- 


\begin{tabular}{|c|c|c|c|c|c|c|c|c|c|}
\hline \multirow{3}{*}{ Measure } & \multirow{3}{*}{ Attribute } & \multicolumn{8}{|c|}{ Successional stage and age class } \\
\hline & & \multicolumn{2}{|c|}{$\begin{array}{l}\text { Early-maturing } \\
\text { seral }\end{array}$} & \multicolumn{2}{|c|}{$\begin{array}{c}\text { Late-maturing } \\
\text { seral }\end{array}$} & \multicolumn{2}{|c|}{$\begin{array}{c}\text { Overmature } \\
\text { seral }\end{array}$} & \multicolumn{2}{|c|}{$\begin{array}{l}\text { Maturing } \\
\text { climax }\end{array}$} \\
\hline & & $70-115$ & $115-130$ & $131-150$ & $151-170$ & $171-190$ & $191-210$ & $211-230$ & $>230$ \\
\hline DWM volume & $\mathrm{m}^{3} / \mathrm{ha}$ of DWM & 77.8 & 86.4 & 63.6 & 78.2 & 117.0 & 125.4 & 83.4 & 140.9 \\
\hline DWM density & \# Intercepts of DWM per $100 \mathrm{~m}$ & 22.6 & 23.8 & 16.0 & 26.0 & 29.6 & 42.8 & 22.5 & 42.8 \\
\hline DWM diameter & Mean diameter $(\mathrm{cm})$ of DWM & 18.2 & 16.4 & 16.2 & 15.1 & 17.1 & 15.9 & 16.3 & 16.1 \\
\hline DWM decay & Mean DWM decay class $(1-7)^{\mathrm{a}}$ & 5.9 & 5.5 & 5.4 & 5.4 & 4.9 & 4.6 & 4.6 & 4.9 \\
\hline $\begin{array}{l}\text { DWM diameter } \\
\text { variation }\end{array}$ & $\begin{array}{l}\text { Mean (within-stand) coefficient } \\
\text { of variation }\end{array}$ & 35.9 & 32.2 & 29.3 & 31.9 & 40.1 & 31.1 & 35.1 & 33.4 \\
\hline $\begin{array}{l}\text { DWM decay class } \\
\text { variation }\end{array}$ & $\begin{array}{l}\text { Mean (within-stand) coefficient } \\
\text { of variation of CWD decay class }\end{array}$ & 17.7 & 22.4 & 30.6 & 28.4 & 33.4 & 24.9 & 33.7 & 29.2 \\
\hline Snag basal area & Basal area $\left(\mathrm{m}^{2} / \mathrm{ha}\right)$ & 2.5 & 5.0 & 5.0 & 6.4 & 8.8 & 10.3 & 10.4 & 10.8 \\
\hline Snag density & \# Snags/ha & 133 & 202 & 229 & 227 & 230 & 362 & 288 & 314 \\
\hline Snag height & Mean snag height (m) & 10.1 & 9.6 & 9.6 & 10.9 & 9.6 & 10.7 & 10.0 & 9.6 \\
\hline Snag diameter & $\begin{array}{l}\text { Mean snag diameter }(\mathrm{cm}) \text { at } \\
\text { breast height }\end{array}$ & 18.8 & 16.9 & 16.4 & 18.4 & 20.4 & 18.5 & 19.9 & 21.1 \\
\hline Snag decay & Mean decay class $(1-6)^{\mathrm{b}}$ & 3.5 & 3.8 & 3.4 & 3.3 & 4.2 & 3.6 & 3.9 & 3.9 \\
\hline Snag height variation & $\begin{array}{l}\text { Mean (within-stand) coefficient } \\
\text { of variation snag height }(\mathrm{m}) \text {. }\end{array}$ & 29.1 & 33.1 & 36.1 & 35.8 & 39.3 & 32.9 & 38.4 & 44.5 \\
\hline Snag diameter variation & $\begin{array}{l}\text { Mean (within-stand) coefficient } \\
\text { of variation snag dbh. }\end{array}$ & 26.2 & 28.3 & 30.7 & 26.0 & 29.8 & 29.4 & 37.4 & 23.7 \\
\hline Snag decay variation & $\begin{array}{l}\text { Mean (within-stand) coefficient } \\
\text { of variation snag decay class }\end{array}$ & 25.5 & 27.8 & 31.5 & 35.1 & 22.0 & 36.2 & 28.1 & 31.3 \\
\hline Snag spacing variation & $\begin{array}{l}\text { Coefficient of variation "distance } \\
\text { to nearest snag" point-centred } \\
\text { quarter method. }\end{array}$ & 52.6 & 52.2 & 52.9 & 54.6 & 51.4 & 53.0 & 56.0 & 52.6 \\
\hline Live-tree basal area & Basal area $\left(\mathrm{m}^{2} / \mathrm{ha}\right)$ & 52.1 & 53.0 & 57.5 & 60.1 & 49.4 & 60.3 & 61.4 & 56.1 \\
\hline Live-tree stem density & \# Trees /ha & 2000 & 1724 & 1622 & 1492 & 1285 & 1477 & 1255 & 1396 \\
\hline Live-tree height & Mean live-tree height (m) & 13.9 & 14.5 & 15.7 & 16.6 & 14.5 & 14.8 & 16.4 & 14.9 \\
\hline Live-tree diameter & $\begin{array}{l}\text { Live-tree diameter }(\mathrm{m}) \text { at } \\
\text { breast height }\end{array}$ & 19.2 & 20.2 & 20.8 & 22.4 & 20.5 & 21.6 & 23.5 & 21.6 \\
\hline Live-tree height variation & $\begin{array}{l}\text { Mean (within-stand) coefficient } \\
\text { of variation of tree dbh. }\end{array}$ & 17.9 & 20.6 & 23.4 & 21.5 & 26.2 & 21.8 & 27.3 & 25.6 \\
\hline Live-tree age variation & $\begin{array}{l}\text { Mean (within-stand) coefficient } \\
\text { of variation of live-tree age } \\
\text { (years) }\end{array}$ & 16.3 & 16.4 & 20.2 & 19.0 & 23.9 & 26.8 & 22.3 & 25.5 \\
\hline $\begin{array}{l}\text { Live-tree spacing } \\
\text { variation }\end{array}$ & $\begin{array}{l}\text { Coefficient of variation- } \\
\text { distance to nearest tree- } \\
\text { point-centred quarter method. }\end{array}$ & 53.9 & 55.1 & 51.5 & 52.5 & 53.9 & 51.4 & 47.7 & 50.9 \\
\hline Regenerating tree density & $\begin{array}{l}\text { \# Stems/ha of trees } \\
(>0.3 \mathrm{~m} \text { tall and }<1.1 \mathrm{~cm} \mathrm{DBH})\end{array}$ & 1945 & 1818 & 2655 & 2613 & 3020 & 3275 & 5020 & 2500 \\
\hline Sapling tree density & $\begin{array}{l}\text { \# Stems/ha of trees } \\
(<1.0 \mathrm{~m} \text { tall and }<7.1 \mathrm{~cm} \mathrm{DBH})\end{array}$ & 781 & 1155 & 2381 & 907 & 1500 & 1225 & 1300 & 1875 \\
\hline Forb species richness & \# forb species per plot & 10.6 & 9.7 & 10.7 & 8.1 & 9.2 & 6.1 & 10.4 & 8.1 \\
\hline Duff depth & Depth to organic layer $(\mathrm{cm})$ & 11.7 & 13.3 & 16.2 & 16.7 & 16.6 & 13.7 & 19.4 & 15.6 \\
\hline
\end{tabular}

a Decay class 1 = least decay; Decay class $6=$ most decay.

becay class $1=$ least decay; Decay class $7=$ most decay.

munities. The delineation of these stages is based on observed changes in old-growth attributes through the eight age classes used for data summary and analysis.

\section{Early-maturing Seral (70-130 years)}

These stands were characterized by high live-tree stem density composed mainly of relatively short and small-diameter lodgepole pine. White spruce and subalpine fir generally made up less than $10 \%$ of the tree basal area. Early maturing seral lodgepole stands exhibited very low variation in stand height, dbh, and age. High stem densities blocked light and reduced the density of regenerating conifers in the understorey. The youngest stands sampled in this study had already experienced disturbance and structural legacies of the previous stand were present but had largely disappeared. Downed woody mate- rial volume and density were very low and were composed of large-diameter logs of advanced decay from the pre-fire stand, and recently fallen small-diameter logs from the current stand. Variation in DWM diameter was high. Snag density and basal area were low in early maturing seral stands. Snags in the middecay (classes 4 and 5) and mid-diameter $(21-30 \mathrm{~cm})$ ranges were very rare. Snags were spaced evenly in the stand and exhibited low variability in height and dbh. The duff layer was generally thin in maturing seral stands $(<12 \mathrm{~cm})$.

In summary, early maturing seral stands with few exceptions did not support stand structural attributes indicative of old-growth conditions. At this stage in stand development, structure in the form of snags and DWM from the previous stand was on the way out, and the stand had not yet progressed to the point that additional older structures were being generated. 
Table 3. Summary of univariate statistical analyses

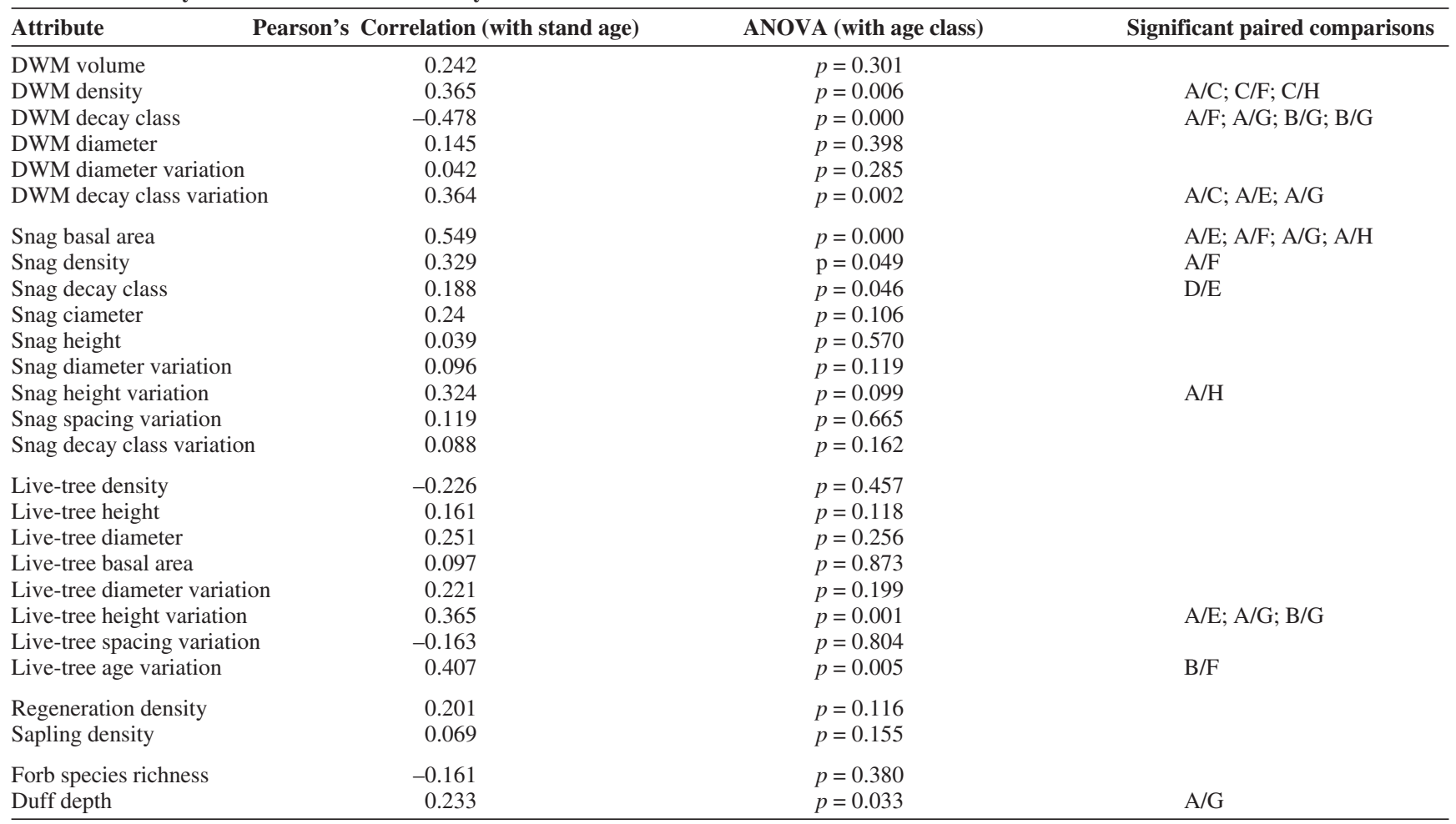

Stand Age-Class Legend

$\mathrm{A}=70-115$ years; $\mathrm{B}=116-130$ years $\mathrm{C}=131-150$ years; $\mathrm{D}=151-170$ years; $\mathrm{E}=171-190$ years;

$\mathrm{F}=191-210$ years; $\mathrm{G}=211-230$ years; $\mathrm{H}=>230$ years;

\section{Late-maturing Seral (131-170 Years)}

During this stage, the abundance of white spruce and subalpine fir composition in the tree overstorey increased rapidly (Fig. 3). The original lodgepole pine tree cohort increased in size at the beginning of this stage but declined in terms of composition and vigour towards the end. Overall live-tree density, height, dbh, and basal area all increased significantly through this stage, as did the degree of variation in live-tree height, dbh, and age. The abundance of regenerating conifers in the understorey, especially those of sapling size, increased as white spruce and subalpine fir grew to the young tree stage. The volume and density of DWM remained low during this stage and was made up of a greater proportion of newly fallen lodgepole pine in the hard decay stages (classes 1 and 2). There was low variation in the diameter of DWM and slightly higher variation in decay stage. Snag basal area and density remained as low as during the early maturing seral stage and exhibited similar distribution of size. A higher proportion of early snag decay stages occurred in this successional stage, as lodgepole pine died and remained standing. Variation in snag $\mathrm{dbh}$ and height remained low although slightly higher than in the early maturing seral stage. The variation in spacing of snags increased rapidly during the latter half of this stage (151-170 years) as a result of random death of older lodgepole pine trees.

In summary, during the beginning of the late maturing seral stage rapid growth of live trees occurred, including the progression of young spruce and fir into the canopy. Toward the end of this stage, lodgepole pine trees began to die and a small increase in snag basal area occurred. Very little additional DWM was contributed as few lodgepole pine trees had fallen at this stage.

\section{Overmature Seral (171-230 Years)}

Tangible increases in many structural attributes occurred at this stage in the successional sequence. These occurrences were triggered primarily by advanced decay and falling of the original post-fire lodgepole pine trees. Lodgepole pine occurrence in the overstorey reached a low during this time period but spruce and fir continued to increase as a proportion of the tree canopy (Fig. 3). Live-tree basal area, mean height, and mean dbh all declined strongly between 151-190 years as a result of old, large-diameter pine trees falling and young spruce and fir entering the tree overstorey. Live-tree density reached a low in the 171-190-year age class and stabilized through to 230 years. The mean coefficients of variation in live-tree age, dbh, and height increased strongly between age classes 151-170 and 170-190 years, reflecting pine decadence and spruce and fir growth. Conifer regeneration in the understorey increased rapidly through this successional stage.

Major increases in amounts of DWM and snags occurred between age classes 151-170 and 170-190 years. DWM volume increased by $50 \%$, especially noticeable in the hard decay class (recently fallen pine) and in the 21 - to $30-\mathrm{cm}$ size range (Fig. 4). Snag basal area increased by $39 \%$ with snags $>30 \mathrm{~cm}$ and those in advanced decay stages increasing by the greatest proportions (Fig. 5). The proportion of early decay stage snags declined markedly during this stage as pine trees aged rapidly. The variability in DWM and snag size increased noticeably in age class 171-190 years, and the variation in snag spacing declined significantly.

In summary, structural characteristics commonly associated with old growth seem to appear in the overmature seral stage of forest succession (171-230 years). The advanced decay and 


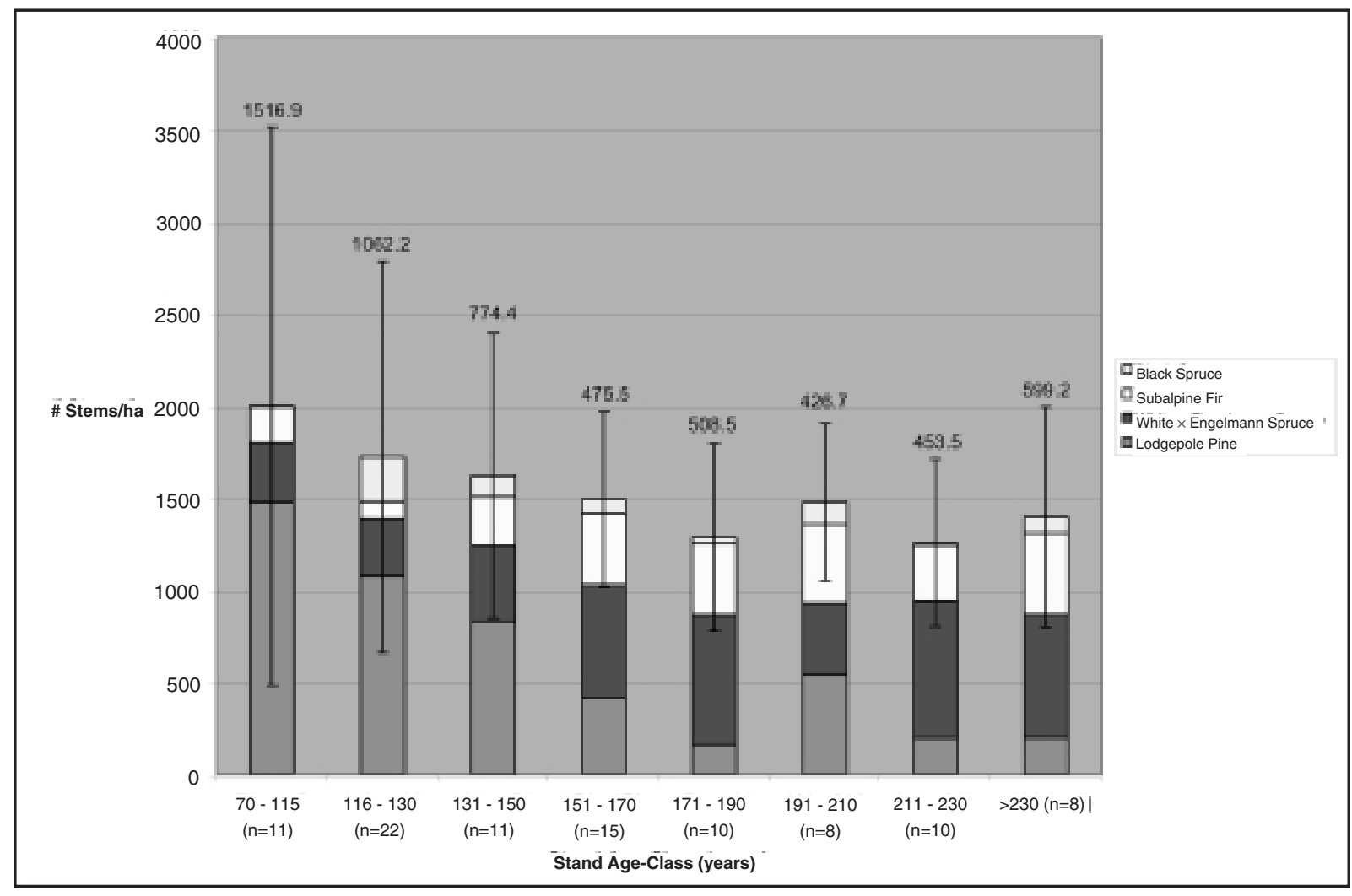

Fig. 3. Changes in composition of live-tree species with stand age.

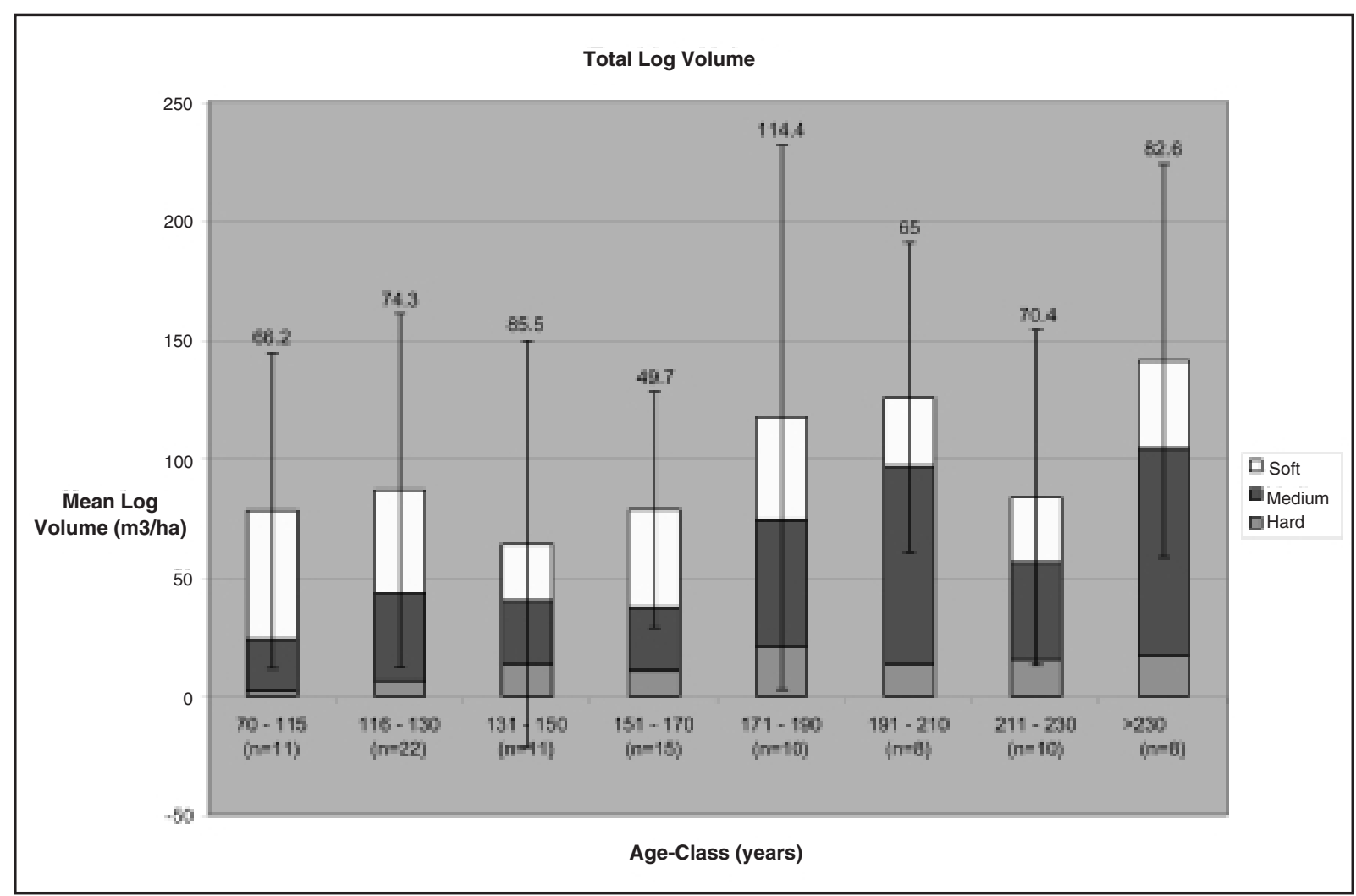

Fig. 4. Changes in downed woody material (DWM) volume and diameter with stand age. 


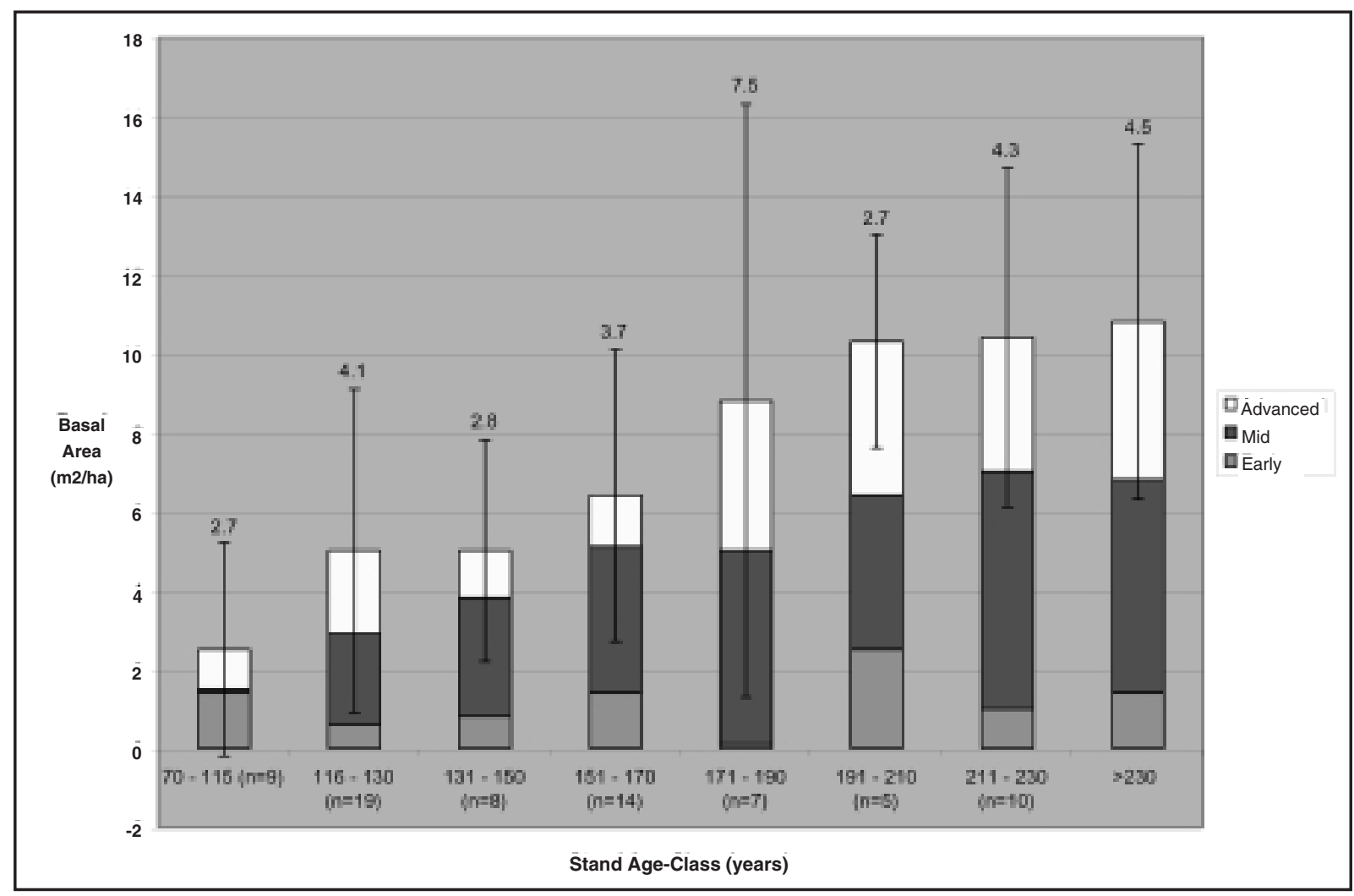

Fig. 5. Changes in basal area and decay of standing snags with stand age.

subsequent falling of standing-dead lodgepole pine trees creates a surge in stand structural complexity, both on the ground and above it. The increased proportion of white/Engelmann spruce and subalpine fir trees in these older stands introduces increased variability in tree size and age.

\section{Maturing Climax (> 230 Years)}

Identification of this stage is difficult because it is unclear if the maximum age of sampled stands represents climax conditions for this region. The attributes studied indicate that certain structural characteristics stabilize, including live-tree density, live-tree age variation, snag density, and snag basal area. Some stand attributes such as DWM volume and variation in snag height reached a clear peak at this age. Other variables, such as DWM variation and conifer regeneration density, declined. Subalpine fir abundance in the live-tree layer increased in this age class but white/Engelmann spruce abundance declined (Fig. 3). Lodgepole pine trees were uncommon in this stage except on dry, west-facing slopes where this species may self-perpetuate to form an edaphic climax.

\section{Old-growth Index}

Old-growth index calculations as presently analysed are preliminary. Preliminary nature notwithstanding, plots with high old-growth scores generally supported stand size, structure, and variability indicative of old growth. Fig. 6 illustrates mean oldgrowth scores for each of the stand age classes. Old-growth index scores correlated strongly with stand age. The correlation coefficient value between "oldest tree age," which was used for age-class distinctions, was $r=.513$. Nine of the ten sample plots with lowest old-growth index scores were in stands aged less than 139 years $($ mean $=129)$. Nine of these lowestscoring stands were mapped by Alberta Vegetation Inventory (AVI) as being 80 to 120 years old. Nine of the ten sample plots with highest old-growth index scores were in stands more than 175 years old $($ mean $=214)$. Nine of these plots were in stands mapped by AVI as being 200 years or older.

\section{Influence of Multiple Factors on "Old Growthness"}

The preceding discussion pertains to the influence of one factor, "stand age," on various individual attributes of old-growth forest structure and composition. Other factors, however, are also likely to modify or supplement the effect of stand age on attributes of forest structure and composition that reflect old growth. Some of these "site factors" include elevation, slope aspect, slope angle, moisture regime, and soil properties. Multiple regression was used to assess which site factors affected old-growth attributes appreciably and to estimate the relative magnitudes of the contributions of these factors. We used the cumulative old-growth index score as the measure of old growth (dependent variable). Site factors (independent variables) were stand age, slope angle, slope aspect, elevation, and percent composition of lodgepole pine. The latter factor was incorporated into the analysis as a surrogate for stand age and because of its potential utility for future predictive old-growth mapping.

Multiple regression showed that only stand age $(p=0.000)$ and percent composition lodgepole pine $(p=0.002)$ significantly affected old-growth scores. The overall model was also highly significant $(p=0.000)$. Stand age played the greatest role in predicting old-growth index scores (standardized coefficient 


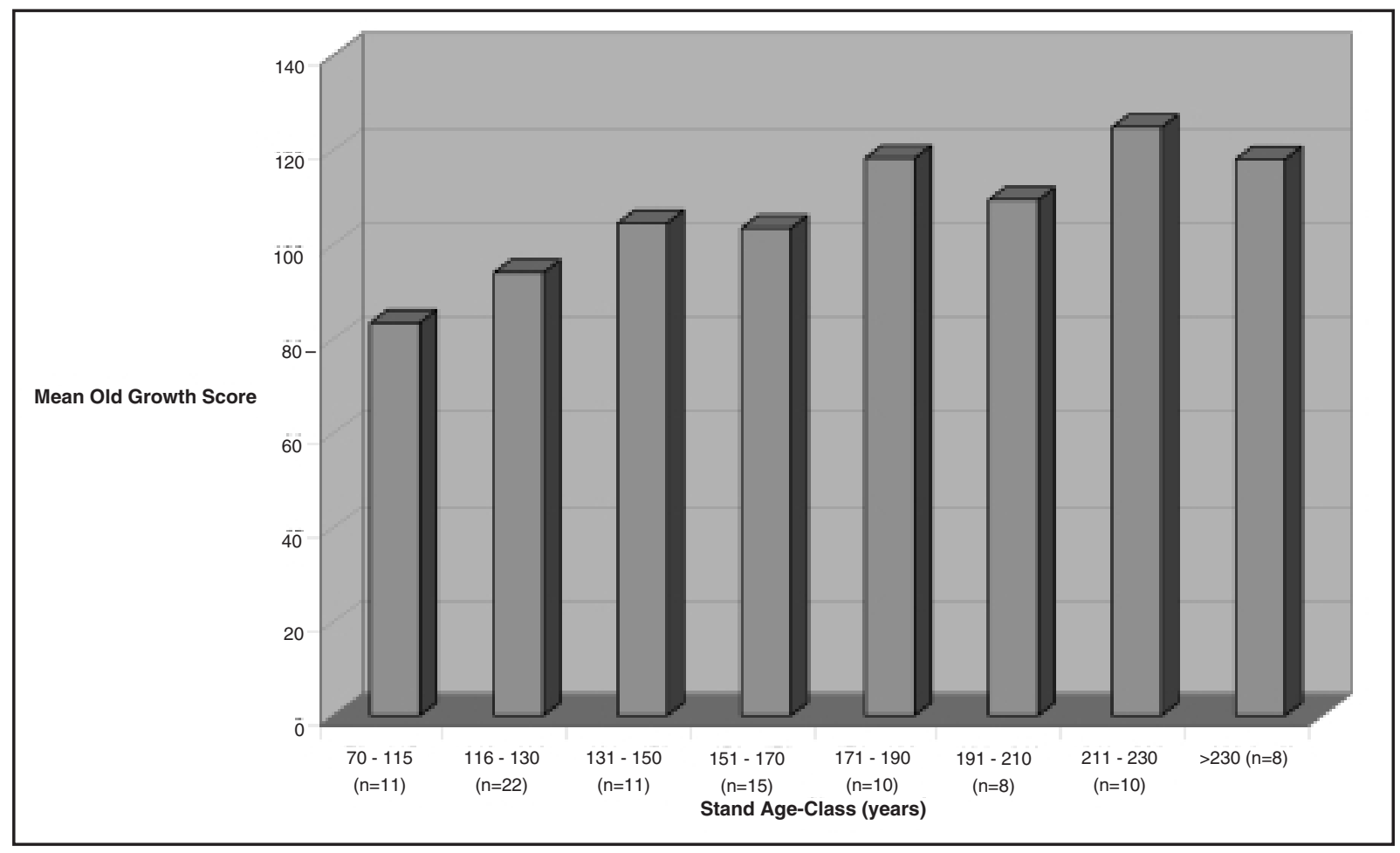

Fig. 6. Changes in mean old-growth index scores with stand age.

$=.439)$. Percent composition of lodgepole pine had a standardized coefficient of -0.351 . Of the other site factors only elevation $(p=0.136)$ appears to have an appreciable affect on oldgrowth index scores. The standardized coefficient of -0.163 indicates that higher elevations tend to support lower oldgrowth index scores. This was noted subjectively in the field especially in the upper elevations of the Subalpine Subregion (> $1900 \mathrm{~m})$. Some subalpine stands, especially on steep, north-facing slopes, do not support lodgepole pine tree growth and, as a result, lack the pulse of structure resulting from pine mortality. This factor lowered old-growth scores of stands at higher elevations.

It was noted in the field that riparian sites differed in a number of ways from upland sites of similar age. These sites tended to be more moist and supported different understorey plant life. Lodgepole pine was not common in these sites because of moist soil conditions. Because the breakdown of the original pine cohort contributes greatly to downed woody material and snags, riparian sites tended to support less abundant DWM and snags, especially in the 150- to 200-year range. Coarse woody debris in riparian sites tends to accumulate at greater ages when the original spruce cohort breaks down. Further sampling of forests $>230$ years on various sites is required.

\section{Conclusions}

Three main conclusions can be drawn from these data as analysed here. First, there seem to be some specific attributes that separate younger and more mature forests: hence, snag basal area and density, DWM decay stage and density, variation in live-tree age, and variation in live-tree age and height may be used to describe old-growth conditions. Second, the age of onset of these old-growth attributes, although variable, tends to occur between 160 and 180 years. Third, it appears that site fac- tors other than stand age (e.g., elevation, aspect, slope angle, moisture regime) contribute to the development of structural characteristics that describe old growth. Additional research is needed to understand the ecological significance of stands older than 160-180 years of age in maintaining biodiversity elements within a managed forest landscape. Nonetheless, Weyerhaeuser Company in Alberta will use these initial results in its long-term forest planning. Retention targets currently identified in Weyerhaeuser forest management planning in the Upper Foothills and Subalpine subregions of Alberta will focus on ensuring that forests older than 180 years of age are sustained over the planning horizon. Further research will assist in identifying amounts and geographical location.

\section{References}

Achuff, P.L. 1989. Old-growth forests of the Canadian Rocky Mountain National Parks. Natural Areas Journal 9 (1): 12-26

Alberta Environmental Protection. 1994. Natural regions and subregions of Alberta: summary. Alberta Environmental Protection, Edmonton, AB. Publication No. I/531.

AFCSSC (Alberta Forest Conservation Strategy Steering Committee). 1997. Alberta Forest Conservation Strategy. Alberta Environmental Protection, Edmonton, AB.

Burton, P., D. Kneeshaw, and D. Coates. 1999. Managing forest harvesting to maintain old growth in boreal and sub-boreal forests. The Forestry Chronicle 75: 623-631.

Clark, D.F., D.D. Kneeshaw, P.J. Burton and J.A. Antos. 1998. Coarse woody debris in sub-boreal spruce forests of west-central British Columbia. Canadian Journal of Forest Research 28: 284-290.

Farr, D. 1993. Bird abundance in spruce forests of west-central Alberta: the role of stand age. In D.H. Kuhnke (ed.). Birds of the boreal forest, workshop proceedings, March 10-12, 1992, Prince Albert, Saskatchewan. pp. 55-62. Northern Forestry Centre, Edmonton, Alberta. 
Gandhi, K.J.K., J.R. Spence, D.W. Langor, D.W. and L.E. Morgantini. 2001. Fire-residuals as habitat reserves for epigaeic beetles (Coleoptera: Carabidae and Staphylinidae). Biological Conservation 102: 131-141.

Hunter, M.L. Jr. and A.S. White. 1997. Ecological thresholds and the definition of old-growth forest stands. Natural Areas Journal 17 (4): 292-296.

Johnson, E.A. 1992. Fire and vegetation dynamics: studies for the North American boreal forest. Cambridge University Press, Cambridge, UK. 129 p.

Kirk, D., A. Diamond, K. Hobson and A. Smith. 1996. Breeding bird communities of the western and northern boreal forest: relationship to forest type. Canadian Journal of Zoology. 74: 1749-1770.

Lee, P., S. Crites and J.B. Stelfox. 1995. Changes in forest structure and floral composition in a chronosequence of aspen mixedwood stands in Alberta. In J.B. Stelfox (ed.). Relationships between stand age, stand structure, and biodiversity in aspen mixedwood forests in Alberta. pp. 29-48. Jointly published by Alberta Environmental Centre (AECV95-R1), Vegreville, Alberta, and Canadian Forest Service (Project No. 0001A). Edmonton, Alberta.

Lee, P., S. Hanus and B. Grover. 2000. Criteria for estimating old growth in boreal mixedwoods from standard timber inventory data Forest Ecology and Management 129: 25-30.

Moir, W.H. 1992. Ecological concepts in old-growth forest definition. In Old-growth Forests in the Southwest and Rocky Mountain Regions. Proceedings of a workshop. pp. 18-23. Portal, Arizona, USDA General Tech. Rep. RM-213.

Mueller-Dombois, D. and H. Ellenberg. 1974. Aims and Methods of Vegetation Ecology. John Wiley and Sons. 547 p.

Neter, J., W. Waserman and M.H. Kutner. 1990. Applied Linear Statistics Models, Irwin, Homewood. IL.

Peterson, E.B., N.M. Peterson and K.A. Enns. 1995. Guidelines for old-forest management in Elk Island, Jasper, Yoho, Kootenay, Banff and Waterton Lakes National Parks. Prepared for Canadian Heritage Parks Canada, Alberta Region by Western Ecological Services Ltd. Victoria, B.C. 78 p.
Pettapiece, W.W. 1986. Physiographic Subdivisions of Alberta. Agriculture Canada.

Rogeau, M.P. 1996. Understanding age-class distribution in the southern Canadian Rockies. M.Sc. Thesis. University of Alberta, Edmonton, Alberta. $139 \mathrm{p}$.

Roy, L.D., J.B. Stelfox and J.W. Nolan. 1995. Relationships between mammal biodiversity and stand age and structure in aspen mixedwood forests in Alberta. In J.B. Stelfox (ed.). Relationships between stand age, stand structure, and biodiversity in aspen mixedwood forests in Alberta. pp. 159-190. Jointly published by Alberta Environmental Centre (AECV95-R1), Vegreville, Alberta, and Canadian Forest Service (Project No. 0001A). Edmonton, Alberta.

Schneider, R. 2000. Old-growth forests in Alberta: ecology and management. Draft Report. Alberta Centre for Boreal Research. Available online at: http://www.borealcentre.ca/reports/ old_grow/ old_grow.html.

Stelfox, J.B., Editor. 1995. Relationships between stand age, stand structure, and biodiversity in aspen mixedwood forests in Alberta. Jointly published by Alberta Environmental Centre (AECV95-R1), Vegreville, Alberta, and Canadian Forest Service (Project No. 0001A). Edmonton, Alberta. 308 p.

Strong, W.L. 1992. Ecoregions and ecodistricts of Alberta. Volume 3. Prep. for Alberta Forestry, Lands and Wildlife, Resource Information Branch by Ecological Land Surveys Ltd. Edmonton, AB. 259 p.

Watson, B.G. 1993. Canadian views on old-growth forests. Forestry on the Hill Special Issue 5: 1-2.

Wehrhahn, R.L. 1982. Forage Inventory of the Chungo-ClineNordegg Study Area. Alberta Energy and Natural Resources Report N0. T/19-No. 4. 